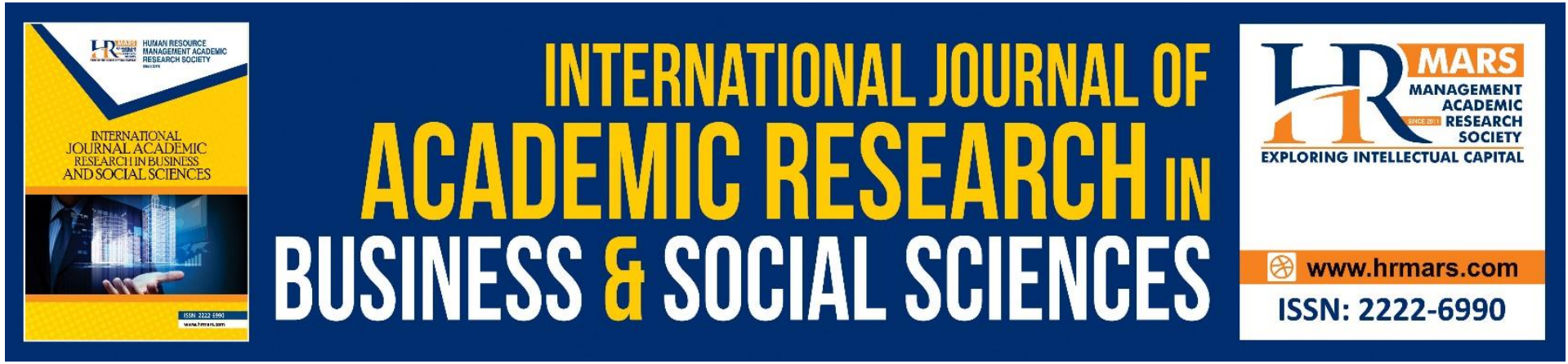

\title{
Factors Affecting International Competitiveness of Tourism Services Trade: Evidence from Zhejiang Province, China
}

Lujiao Xiang, QianQian Chen

To Link this Article: http://dx.doi.org/10.6007/IJARBSS/v11-i8/10074

DOI:10.6007/IJARBSS/v11-i8/10074

Received: 08 June 2021, Revised: 27 June 2021, Accepted: 17 July 2021

Published Online: 06 August 2021

In-Text Citation: (Xiang \& Chen, 2021)

To Cite this Article: Xiang, L., \& Chen, Q. (2021). Factors Affecting International Competitiveness of Tourism Services Trade: Evidence from Zhejiang Province, China. International Journal of Academic Research in Business and Social Sciences, 11(8), 125-139.

Copyright: (c) 2021 The Author(s)

Published by Human Resource Management Academic Research Society (www.hrmars.com)

This article is published under the Creative Commons Attribution (CC BY 4.0) license. Anyone may reproduce, distribute, translate and create derivative works of this article (for both commercial and non-commercial purposes), subject to full attribution to the original publication and authors. The full terms of this license may be seen at: http://creativecommons.org/licences/by/4.0/legalcode

Vol. 11, No. 8, 2021, Pg. 125 - 139

http://hrmars.com/index.php/pages/detail/IJARBSS

JOURNAL HOMEPAGE

Full Terms \& Conditions of access and use can be found at http://hrmars.com/index.php/pages/detail/publication-ethics 


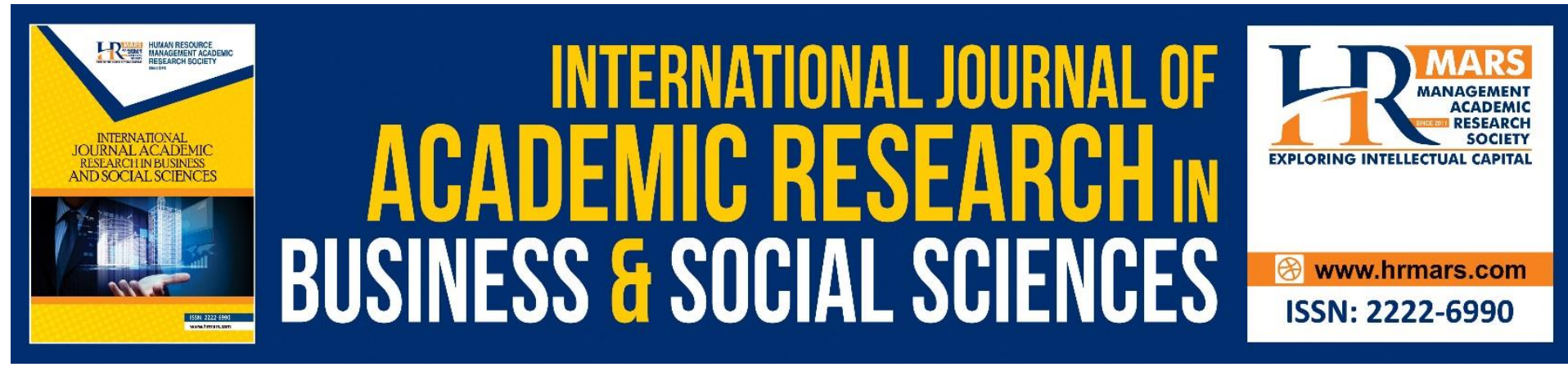

\title{
Factors Affecting International Competitiveness of Tourism Services Trade: Evidence from Zhejiang Province, China
}

\author{
Lujiao Xiang, QianQian Chen \\ Zhejiang University of Science and Technology, China \\ Email: lissiechen@gmail.com
}

\begin{abstract}
As one of the traditional service trade modes, tourism service trade is an important part of service trade and is the main driving force for the rapid growth of China's service trade. Zhejiang is famous for its rich tourism resources and there are many natural and cultural landscapes with high ornamental value and rich cultural heritage. As a result, the tourism industry in Zhejiang has developed rapidly. Under this background, this paper first studies the development situation of the tourism service trade in Zhejiang Province from four aspects. And then this paper uses the latest data and makes an empirical analysis on its influencing factors by using the regression method and explore the restrictive factors affecting the improvement of competitiveness. Finally, based on the current situation and influencing factors of Zhejiang's tourism service trade, this paper puts forward the corresponding countermeasures and suggestions which hopefully could help Zhejiang Province find a way to promote tourism service trade in regional coordinated development.
\end{abstract}

Keywords: Tourism Service Trade, International Competitiveness, Influencing Factors, China

\section{Introduction}

The service economy of China has been rising in recent years, and the service trade has developed rapidly. From the current global trade development trend, it can be seen that the growth rate of trade in goods is decreasing year by year, while service trade is contrary. As one of the traditional service trade forms, tourism service trade is an important part and one of the most strategic and comprehensive industries. It has the characteristics of high market openness and it can further promote the development of the tertiary industry. Its development is in line with the trend of industrial transformation and modernization in China. Tourism trade is also the main driving force for the rapid growth of China's service trade.

As a province with rich natural and cultural landscapes, the tourism industry in Zhejiang has developed rapidly. This paper analyzes the current situation of the tourism service trade in Zhejiang Province from four aspects of the development scale, structure, tourist source, and regional development situation.

As an important part of service trade, the promotion of tourism competitiveness is the key to make the tourist destination win in the fierce competition, and the promotion of tourism competitiveness must be based on the scientific and reasonable quantitative evaluation.The 
study focuses on the empirical research of the international competitiveness of tourism service trade in Zhejiang Province, and based on Michael Porter's Diamond Model, constructs a multiple regression model to analyze the factors affecting this competitiveness, which could enrich empirical research on the international competitiveness of tourism service trade. Based on the current situation and influencing factors of Zhejiang's tourism service trade, this paper puts forward the corresponding countermeasures and suggestions, hoping that Zhejiang Province can find a way to promote tourism service trade in regional coordinated development.

\section{Literature Review}

Under the wave of economic globalization, the service trade has become a new engine of economic growth, while the service trade level has become an important standard to measure a country's international competitiveness. Scholars have made fruitful achievements in the research on the competitiveness of the tourism service trade.

Crotts et al (1998) studied the determinants of promoting the development of international tourism service trade from the perspective of suppliers and wholesalers. B. Tadesse and R. white (2011) studied whether the phenomenon of immigration in the United States had a certain impact on its tourism service trade. They used the Stone-Geary Utility Function Model to conduct an empirical study, and concluded that immigration would affect the tourism service trade of the United States, especially the export of the tourism service trade. Jensen and Zhang (2013) conducted research from the perspective of the supply side, studying the impact of Internet penetration, the safety factor, and infrastructure conditions of tourist attractions on the international competitiveness of tourism service trade. Hanna et al (2015) pioneered the use of the latest model in intra-industry trade theory to independently test the factors that determine the differentiation of service trade both vertically and horizontally. They concluded that to a large extent, the determinants of tourism specialization in most developed countries were the same as those of intra-industry trade of commodities. Kesgin (2019) pointed out that the hospitality of residents in tourist destinations had a positive effect on the destination image.

Some scholars conducted empirical analysis on the factors affecting the tourism service trade competitiveness. The method of establishing a multiple regression model is usually adopted, and the selected indicators are usually based on several major factors in the Diamond Model theory (production factors, demand conditions, performance of related industries, and supporting industries). For example, Geng et al. (2018) selected variables from resource endowment and environmental system constraints, based on the Diamond Model and the characteristics of tourism industry, to construct a multiple regression model to analyze the influencing factors of China's tourism service trade competitiveness, and concluded that the number of starred hotels, trade openness, human resources and foreign investment were; positively correlated with trade export volume; Ge et al. (2011) established a regression model to analyze the influencing factors of Shanghai's tourism competitiveness, and concluded that the original value of tourism fixed assets, the number of tourism employees, the number of foreign-funded starred hotels and the total labor productivity of tourism industry were all influencing factors; Chen En et al (2015) used regression model to analyze the influencing factors of Macao's tourism competitiveness, and found that Macao's tourism foreign exchange income was mainly affected by the labor efficiency of tourism industry, per capita consumption of inbound tourists and hotel occupancy rate. 
Some competitiveness evaluation systems study the influencing factors at the same time, such as factor analysis and principal component analysis. For example, Duchun et al (2014) used principal component analysis combined with regression analysis to measure the influencing factors of tourism competitiveness in Heilongjiang Province. Other scholars choose other methods. For example, Li et al. (2018) found that government, human capital, and capital investment were the influencing factors based on the gray correlation model; Based on the extended gravity model, Guo (2019) found that the per capita GDP, geographical distance, free trade agreement and relative trade freedom of trading countries would affect trade competitiveness.

To date, there are still lack of provincial-level comprehensive studies in the international competitiveness of the tourism trade in China. Zhang (2017) built a multi-index comprehensive evaluation index system to study the tourism service trade competitiveness of Zhejiang Province and put forward suggestions to improve it. Some research theoretically analyzed the international competitiveness of tourism service trade in Zhejiang Province according to the Diamond Model, and pointed out the problems existing in the development of the tourism service trade in Zhejiang Province and put forward the corresponding countermeasures.

Based on reviewing the previous literature, it is founded that most of whom make model modifications based on comparative advantage and competitive advantage. Scholars usually use some commonly used trade competitiveness indicators or index systems for empirical analysis and evaluation, and some other scholars use Porter's theory of national competitiveness advantage to make an empirical analysis of the influencing factors. The theoretical basis of this research is generally comparative advantage and the diamond model. On the whole, the goal of the researches about the competitiveness of the tourism service trade is from simple analysis to problem-solving. In the beginning, scholars only analyzed the competitiveness of China's tourism service trade, and then began to study the influencing factors of competitiveness, and gradually put forward corresponding suggestions. Most scholars use the multiple regression model to analyze the influencing factors of regional tourism competitiveness, while a small number of scholars innovatively use the grey correlation model and extended gravity model to analyze the influencing factors.

\section{Current Situation of Tourism Service Trade in Zhejiang Province}

Zhejiang Province is located in the Yangtze River Delta area along the southeast coast of China. It is the birthplace of Wuyue culture and Jiangnan culture. Since ancient times, it has been known as a tourist resort. Zhejiang Province has 260000 square kilometers, more than 3000 islands, where hills and mountains account for about $70 \%$ of the land area, and there are more than 800 geomorphic landscapes and more than 200 water landscapes. It is a wellknown tourism province integrating natural scenery and cultural landscape.

\section{Development Scale of Tourism Service Trade in Zhejiang}

Relying on the inherent advantages of tourism resources, Zhejiang Province has vigorously developed the tourism industry. It has effectively protected and developed the natural, historical, and cultural resources expanded the tourism market. Therefore, to a certain extent, it has achieved remarkable results. As shown in the figure (see Figure 1), in the past 20 years, both domestic tourism earning and foreign exchange earnings have been on the rise, indicating that the scale of the tourism service industry in Zhejiang Province has been 
expanding continuously in the past 20 years (Note: after 2018, due to the adjustment of international tourism statistics caliber, the data has declined).

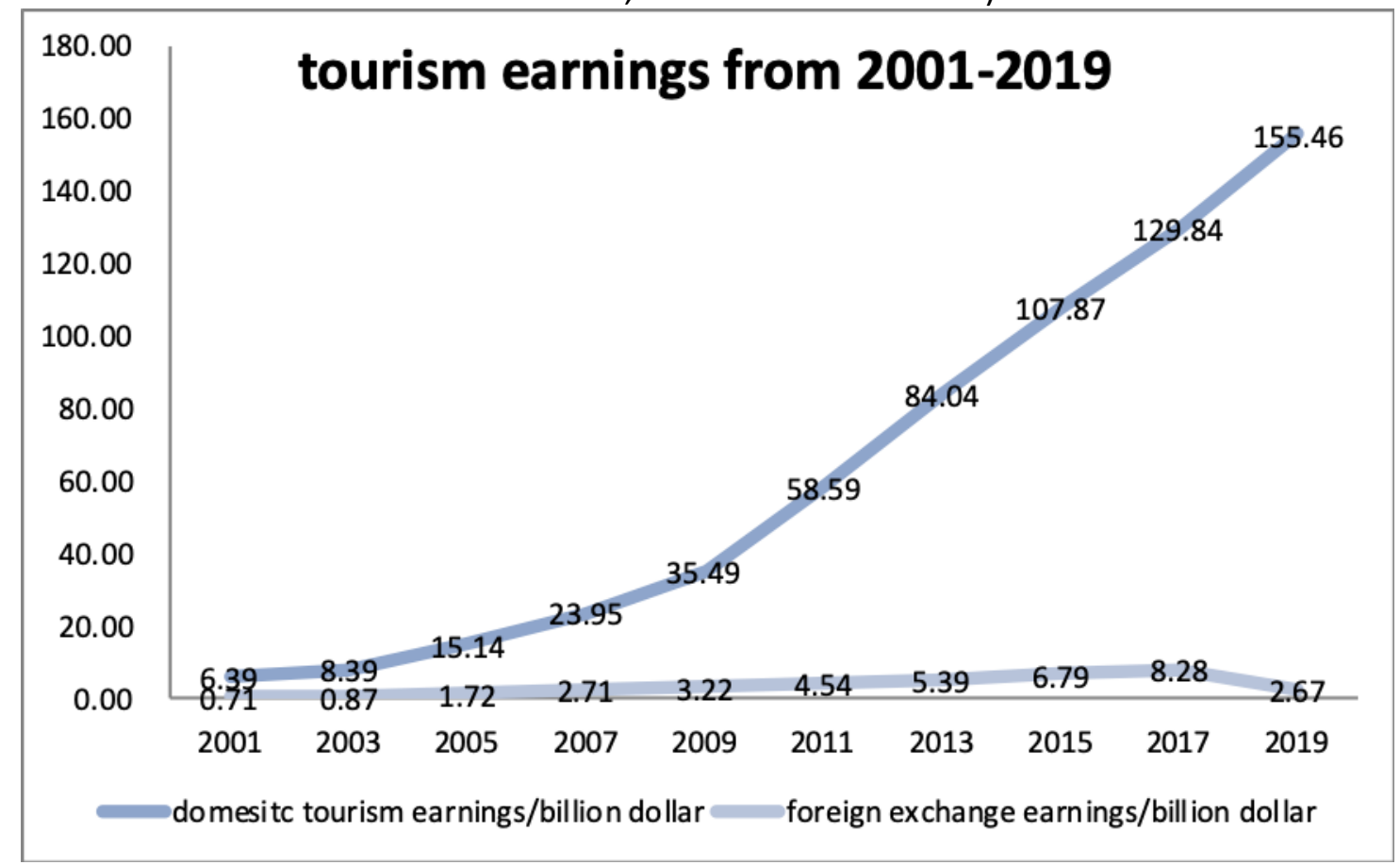

Figure 1: Tourism earnings from (2001-2019)

Data source: calculated according to Zhejiang statistical yearbooks

\section{Structure of Tourism Service Trade in Zhejiang}

It can be seen from the figure that the trade structure of international tourism service in Zhejiang Province is unbalanced, with the consumption expenditure of inbound tourists mainly concentrated in long-distance transportation (see Figure 2). The foreign exchange income of catering and shopping accounts for $31.2 \%$ of the total income. As the most important part of tourism consumption expenditure, the proportion of tourism expenses in scenic spots is only $2.4 \%$, while the proportion of transportation expenses is $30.6 \%$. This shows that most of the tourist funds are spent on long-distance transportation, which also reflects the lack of integrity in the exploitation and planning of tourism resources and transportation infrastructure in Zhejiang Province. The consumption potential of inbound tourists has not been fully exploited, which may even cause tourists to have no in-depth understanding of the culture of the tourist destination. 


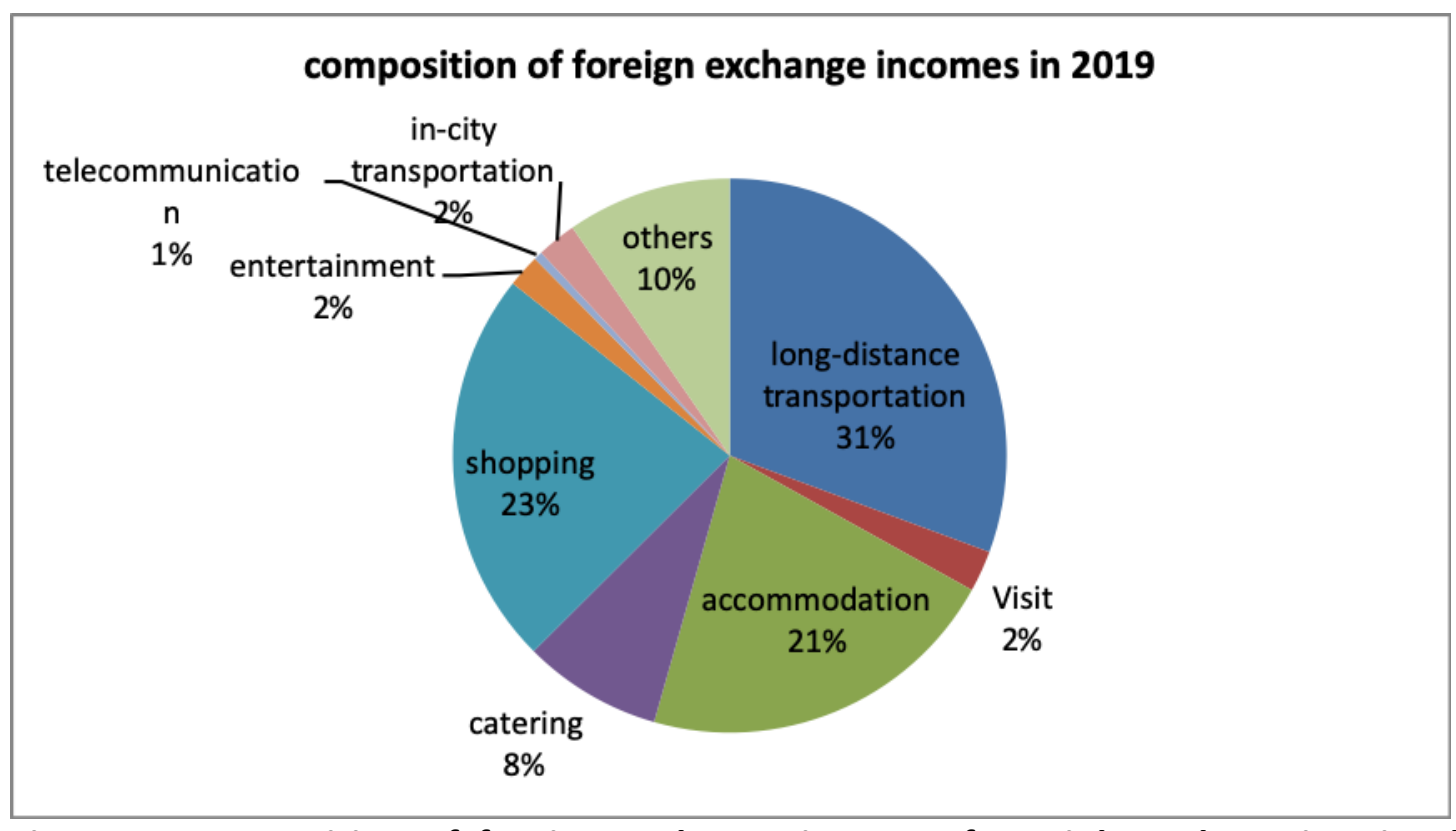

Figure 2: Composition of foreign exchange incomes from inbound tourism in Zhejiang Province in 2019

Data source: calculated according to Zhejiang statistical yearbooks

\section{Analysis of Tourist Source of Tourism Service Trade in Zhejiang}

From 2000 to 2019, the number of inbound tourists in Zhejiang Province increased from 1.47 million to 4.67 million. The table below shows the top ten source countries of inbound tourists in Zhejiang Province (see Table 1). The number of inbound tourists from the top ten source countries in 2019 accounts for $55 \%$ of the total number of inbound tourists. It can be seen from the table that the overseas tourist market in Zhejiang Province is relatively rich, showing diversification. And the number of tourist source countries and inbound tourists is generally on the rise. South Korea, the United States, and Japan are the main source countries of tourists, and these three countries are in the top three in recent five consecutive years. The proportion of Indian tourists has increased in recent two years, and Australia has also entered the top ten in recent two years. 
Table 1: Top 10 source countries of inbound tourists in Zhejiang Province

\begin{tabular}{|c|c|c|c|c|c|c|c|c|c|c|}
\hline \multirow{2}{*}{$\begin{array}{l}\text { Ra } \\
\mathrm{nk}\end{array}$} & \multicolumn{2}{|l|}{2015} & \multicolumn{2}{|l|}{2016} & \multicolumn{2}{|l|}{2017} & \multicolumn{2}{|l|}{2018} & \multicolumn{2}{|l|}{2019} \\
\hline & $\begin{array}{l}\text { Countr } \\
y\end{array}$ & Ratio & $\begin{array}{l}\text { Countr } \\
y\end{array}$ & Ratio & $\begin{array}{l}\text { Countr } \\
y\end{array}$ & Ratio & $\begin{array}{l}\text { Countr } \\
y\end{array}$ & Ratio & $\begin{array}{l}\text { Countr } \\
y\end{array}$ & Ratio \\
\hline 1 & $\begin{array}{l}\text { South } \\
\text { Korea }\end{array}$ & $\begin{array}{l}16.4 \\
1 \%\end{array}$ & $\begin{array}{l}\text { South } \\
\text { Korea }\end{array}$ & $\begin{array}{l}15.9 \\
7 \%\end{array}$ & $\begin{array}{l}\text { South } \\
\text { Korea }\end{array}$ & $\begin{array}{l}12.8 \\
3 \%\end{array}$ & $\begin{array}{l}\text { South } \\
\text { Korea }\end{array}$ & $\begin{array}{l}12.3 \\
2 \%\end{array}$ & $\begin{array}{l}\text { South } \\
\text { Korea }\end{array}$ & $\begin{array}{l}14.5 \\
0 \%\end{array}$ \\
\hline 2 & Japan & $\begin{array}{l}7.90 \\
\%\end{array}$ & US & $\begin{array}{l}7.60 \\
\%\end{array}$ & Japan & $\begin{array}{l}9.09 \\
\%\end{array}$ & US & $\begin{array}{l}10.4 \\
2 \%\end{array}$ & US & $\begin{array}{l}10.5 \\
6 \%\end{array}$ \\
\hline 3 & US & $\begin{array}{l}7.21 \\
\%\end{array}$ & Japan & $\begin{array}{l}7.55 \\
\%\end{array}$ & US & $\begin{array}{l}7.94 \\
\%\end{array}$ & Japan & $\begin{array}{l}9.63 \\
\%\end{array}$ & Japan & $\begin{array}{l}8.42 \\
\%\end{array}$ \\
\hline 4 & Italy & $\begin{array}{l}4.19 \\
\%\end{array}$ & Italy & $\begin{array}{l}4.10 \\
\%\end{array}$ & $\begin{array}{l}\text { Malays } \\
\text { ia }\end{array}$ & $\begin{array}{l}4.15 \\
\%\end{array}$ & India & $\begin{array}{l}3.63 \\
\%\end{array}$ & $\begin{array}{l}\text { Malays } \\
\text { ia }\end{array}$ & $\begin{array}{l}4.57 \\
\%\end{array}$ \\
\hline 5 & $\begin{array}{l}\text { Malays } \\
\text { ia }\end{array}$ & $\begin{array}{l}3.80 \\
\%\end{array}$ & $\begin{array}{l}\text { Malays } \\
\text { ia }\end{array}$ & $\begin{array}{l}3.68 \\
\%\end{array}$ & Italy & $\begin{array}{l}3.55 \\
\%\end{array}$ & $\begin{array}{l}\text { Malays } \\
\text { ia }\end{array}$ & $\begin{array}{l}3.50 \\
\%\end{array}$ & India & $\begin{array}{l}3.88 \\
\%\end{array}$ \\
\hline 6 & $\begin{array}{l}\text { Germa } \\
\text { ny }\end{array}$ & $\begin{array}{l}3.37 \\
\%\end{array}$ & $\begin{array}{l}\text { Germa } \\
\text { ny }\end{array}$ & $\begin{array}{l}3.38 \\
\%\end{array}$ & $\begin{array}{l}\text { Germa } \\
\text { ny }\end{array}$ & $\begin{array}{l}3.42 \\
\%\end{array}$ & $\begin{array}{l}\text { Germa } \\
\text { ny }\end{array}$ & $\begin{array}{l}3.43 \\
\%\end{array}$ & $\begin{array}{l}\text { Germa } \\
\text { ny }\end{array}$ & $\begin{array}{l}3.37 \\
\%\end{array}$ \\
\hline 7 & $\begin{array}{l}\text { Singap } \\
\text { ore }\end{array}$ & $\begin{array}{l}3.05 \\
\%\end{array}$ & France & $\begin{array}{l}3.18 \\
\%\end{array}$ & UK & $\begin{array}{l}3.28 \\
\%\end{array}$ & UK & $\begin{array}{l}2.84 \\
\%\end{array}$ & UK & $\begin{array}{l}2.83 \\
\%\end{array}$ \\
\hline 8 & France & $\begin{array}{l}3.03 \\
\%\end{array}$ & UK & $\begin{array}{l}3.08 \\
\%\end{array}$ & France & $\begin{array}{l}3.00 \\
\%\end{array}$ & $\begin{array}{l}\text { Singap } \\
\text { ore }\end{array}$ & $\begin{array}{l}2.47 \\
\%\end{array}$ & $\begin{array}{l}\text { Austral } \\
\text { ia }\end{array}$ & $\begin{array}{l}2.36 \\
\%\end{array}$ \\
\hline 9 & UK & $\begin{array}{l}2.90 \\
\%\end{array}$ & $\begin{array}{l}\text { Singap } \\
\text { ore }\end{array}$ & $\begin{array}{l}2.80 \\
\%\end{array}$ & $\begin{array}{l}\text { Singap } \\
\text { ore }\end{array}$ & $\begin{array}{l}2.99 \\
\%\end{array}$ & $\begin{array}{l}\text { Canad } \\
\text { a }\end{array}$ & $\begin{array}{l}2.36 \\
\%\end{array}$ & $\begin{array}{l}\text { Singap } \\
\text { ore }\end{array}$ & $\begin{array}{l}2.26 \\
\%\end{array}$ \\
\hline 10 & India & $\begin{array}{l}2.47 \\
\%\end{array}$ & India & $\begin{array}{l}2.74 \\
\%\end{array}$ & India & $\begin{array}{l}2.74 \\
\%\end{array}$ & $\begin{array}{l}\text { Austral } \\
\text { ia }\end{array}$ & $\begin{array}{l}2.20 \\
\%\end{array}$ & France & $\begin{array}{l}2.25 \\
\%\end{array}$ \\
\hline
\end{tabular}

Data source: calculated according to Zhejiang statistical yearbooks

\section{Regional Development Situation}

Set the proportion of the number of inbound tourists in the total number in each region of Zhejiang Province for measuring the economic level of tourism. As shown in the figure, Hangzhou has a high proportion, while the rest of the cities only have $51 \%$ (see Figure 3 ). It can be seen that due to the high development and utilization of tourism resources in these areas, the tourism industry of Zhejiang Province is mainly concentrated in Hangzhou, Huzhou, and other cities. Although other cities also have rich resources, the development is slow due to insufficient exploitation and idle resources. Inbound tourists are not guided to other regions, and there is a lack of linkage and cooperation between regions, which is not conducive to the balanced development of the overall tourism industry in Zhejiang Province. To sum up, from the perspective of trade scale, Zhejiang's tourism service trade has a good development trend in the index period, and its foreign exchange income has a sustained growth trend. From the perspective of the market of the source country, the market is diversified. However, from the perspective of the consumption structure of inbound tourists and regional development structure, there is a serious imbalance trend, so both need to be optimized. 


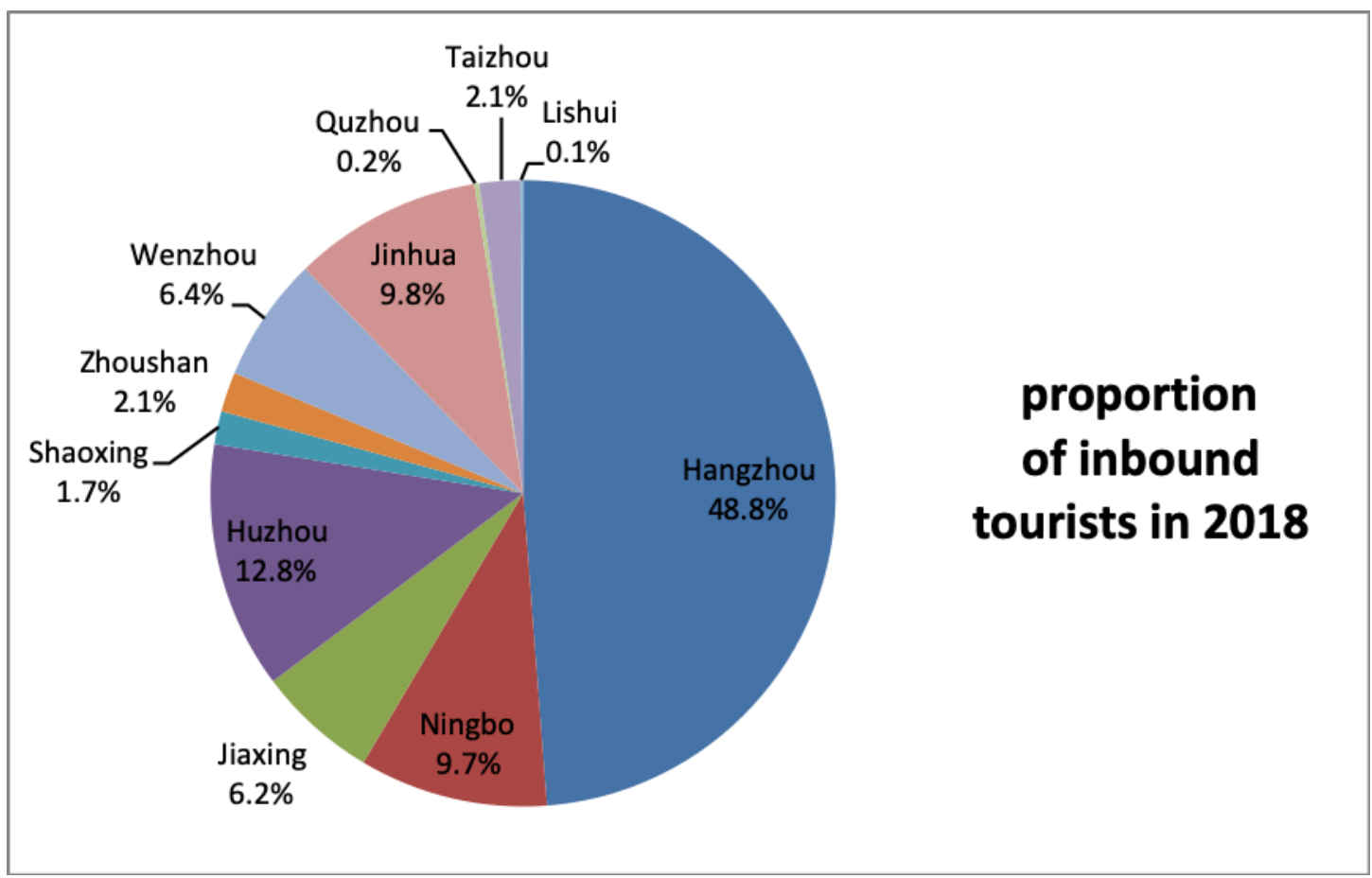

Figure 3: Proportion of inbound tourist in Zhejiang Province in 2018

Data source: calculated according to Zhejiang statistical yearbooks

\section{Empirical Study of the Factors Affecting International Competitiveness of Tourism Service Trade in Zhejiang Province \\ Porter's Diamond Theory model, which has been introduced in the theoretical part, is combined to make an empirical analysis of the influencing factors in this part, to put forward countermeasures and suggestions to improve the international competitiveness of Zhejiang's tourism service trade.}

\section{Index Selection}

1. Selection of dependent variable-- foreign exchange earning of Zhejiang. After looking up a large number of works of literature, it is found that many scholars use the index of international tourism foreign exchange earning when measuring the international competitiveness of tourism service trade (Chen en et al., 2015; Zhao Zhifeng, 2018). Therefore, international foreign exchange earning is representative and can reflect a country's export capacity of tourism service trade, which can reflect the attraction of Zhejiang's tourism products to global tourists.

2. Selection of independent variable-- According to Porter's Diamond Model, considering the multicollinearity and availability of variables, the following independent variables are selected from tourism demand conditions, government support, and tourism-related industries:

(1) Number of star grade hotel--reflects the accommodation ability of inbound tourism Catering and accommodation are a very important part of travel, so according to Porter Diamond Model, catering and accommodation are regarded as supporting industries of tourism, which reflects the tourism service capacity of the place, and is a large part of the source of tourism revenue. The more hotels, the stronger the serviceability and the greater attraction to tourists.

(2) Number of travel agency-- reflects the service ability of inbound tourism 
The travel agency is the most important tourism enterprise for tourism. In the whole tourism activities, the travel agency plays the role of matching all tourism-related industries and tourist attractions for tourists and providing services for tourists based on the results of their selection. Here, the number of travel agencies is chosen as the independent variable, which reflects the scale of the whole tourism industry and the number of competitors in the whole industry.

(3) Number of tourist attraction of A-level and above-- reflects tourism attraction Tourist attractions belong to the production factors of tourism. For a region, the more tourist attractions it has, the higher the quality, it can attract more tourists from all over the world to come, making the tourism earning of the region higher. Therefore, here the number of national A-level and above scenic spots is selected as an independent variable.

(4) Number of international flight-- represents the degree of tourism export convenience Convenient transportation will greatly increase tourists' willingness to travel, so the degree of convenient transportation determines the local tourist attraction to a large extent.

(5) Average exchange rate of RMB to US dollar

The exchange rate must be involved in international travel, and directly related to the foreign exchange income of a region, so this paper will consider it.

\section{Empirical Analysis}

This paper uses the data of Zhejiang Province from 2008 to 2017 for empirical analysis. The data comes from China Statistical Yearbook and Zhejiang Statistical Yearbook. Some missing data are obtained from the official website of the Ministry of Culture and Tourism of the People's Republic of China. The following table is the descriptive statistics of each variable (see Table 2).

Table 2: Descriptive statistics of data

\begin{tabular}{l|lllll}
\hline \multirow{2}{*}{ VARIABLES } & $(1)$ & $(2)$ & $(3)$ & $(4)$ & $(5)$ \\
\hline hotel & $\mathrm{N}$ & $\operatorname{mean}$ & $\mathrm{sd}$ & $\min$ & $\max$ \\
agency & 10 & 865.9 & 24.90 & 829 & 909 \\
attraction & 10 & 1,860 & 253.0 & 1,436 & 2,216 \\
flight & 10 & 379.8 & 158.7 & 211 & 700 \\
E & 10 & 59.50 & 23.37 & 40 & 104 \\
Earning & 10 & 6.537 & 0.310 & 6.140 & 6.950 \\
\hline
\end{tabular}

In order to make the time series stable and reduce the influence of heteroscedasticity on the model, the logarithm method is adopted for each data. In order to understand the correlation among the variables, the paper makes the correlation analysis of six variables with Stata 15. The following table is the correlation analysis of the relevant indicators affecting the competitiveness of the tourism services trade in Zhejiang Province (see Table 3). 
Table 3: Correlation analysis of variables

\begin{tabular}{l|llllll}
\hline & Inhotel & Inagency & Inattr n & Inflight & $\operatorname{lnE}$ & Inearn ${ }^{\prime}$ \\
\hline Inhotel & 1.000 & & & & & \\
Inagency & - & & & & & \\
& $0.775^{* * *}$ & 1.000 & & & & \\
Inattraction & - & & & & & \\
& $0.867^{* * *}$ & $0.906^{* * *}$ & 1.000 & & & \\
Inflight & - & & & & & \\
InE & $0.786^{* * *}$ & $0.799^{* * *}$ & $0.942^{* * *}$ & 1.000 & & \\
Inearning & 0.130 & $-0.620^{*}$ & -0.283 & -0.142 & 1.000 & \\
\hline
\end{tabular}

It can be seen from the table that the four independent variables of hotel, agency, flight, and attraction, have a high correlation, and the two variables of hotel and $E$ have a strong negative correlation with other variables. Therefore, this paper will discuss these six independent variables by principal component analysis.

\section{Principal Component Analysis}

As one of the multivariate statistical analysis methods, principal component analysis can explain most of the information of the original data and only lose a small part after data transformation. It plays a very positive role in revealing the intrinsic nature of things and explaining the internal correlation of variables. One branch of principal component analysis is factor analysis. For indicators with high collinearity, dimension reduction is used to simplify the analysis. These variables tend to show small intragroup differences but large intergroup differences, which has a good effect on removing collinearity between variables.

The total variance explained table is the judgment basis to determine the interpretation degree of the converted principal components (factors) for the original data. It refers to the cumulative variance ratio. Generally, when the total variance is greater than $80 \%$, the analysis result is better and the loss of original information is less. According to the table, the cumulative contribution rate of factor 1 and factor 2 reaches $94.41 \%$, which indicates that the original information is almost retained after dimension reduction (see Table 4). The newly generated two factors can well represent the information content reflected by the original six tourism indicators, so it is reasonable to use the newly generated two factors for further analysis.

Table 4: Total variance explained table

\begin{tabular}{l|llll}
\hline Component & Eigenvalue & Difference & Proportion & Cumulative \\
\hline Comp1 & 3.67204 & 2.62341 & 0.7344 & 0.7344 \\
Comp2 & 1.04863 & .825345 & 0.2097 & 0.9441 \\
Comp3 & .223286 & .18389 & 0.0447 & 0.9888 \\
Comp4 & .0393957 & .0227481 & 0.0079 & 0.9967 \\
Comp5 & .0166476 &. & 0.0033 & 1.0000 \\
\hline
\end{tabular}


Table 5: Principle components (eigenvectors)

\begin{tabular}{l|lllll|l}
\hline Variables & Comp1 & Comp2 & Comp3 & Comp4 & Comp5 & Unexplained \\
\hline Inhotel & -0.4619 & -0.2694 & 0.7820 & 0.3185 & 0.0332 & 0 \\
Inagency & 0.5005 & -0.2457 & -0.0132 & 0.4799 & 0.6772 & 0 \\
Inattraction & 0.5108 & 0.1308 & 0.1765 & 0.4882 & -0.6726 & 0 \\
Inflight & 0.4771 & 0.2613 & 0.5967 & -0.5688 & 0.1569 & 0 \\
InE & -0.2182 & 0.8841 & 0.0322 & 0.3262 & 0.2515 & 0 \\
\hline
\end{tabular}

According to the table, the variables included in the first factor are the number of travel agencies, the number of the star hotel, the number of A-level attractions, and the number of international flights (see Table 5). It can be seen that these four tourism variables basically reflect the tourism and its supporting industries, so the first factor can be regarded as the tourism environmental factor, F1; the second factor only includes the exchange rate, so the second factor can be regarded as the exchange rate factor F2.

\section{Multiple Regression Analysis}

In the empirical study of this paper, the original five independent variables are reduced into two related factors: tourism environment factor and exchange rate factor. The factor scores of these two factors are taken as the data set, and the dependent variable, international tourism foreign exchange earning, will be analyzed by multiple regression, so as to study the factors that affect the foreign exchange earning of inbound tourism, that is, the competitiveness of tourism.

Table 6: Result of regression analysis

\begin{tabular}{l|l}
\hline VARIABLES & $(1)$ \\
In earning \\
\hline F1 & $0.514^{* * *}$ \\
& $(4.32)$ \\
F2 & $-0.463^{*}$ \\
& $(-2.08)$ \\
Constant & $3.469 * * *$ \\
& $(16.03)$ \\
Observations & 10 \\
R-squared & 0.766 \\
F test & 0.00616 \\
r2_a & 0.700 \\
F & 11.49 \\
\hline
\end{tabular}

t-statistics in parentheses

$* * * p<0.01, * * p<0.05, * p<0.1$

Table 7: Result of VIF test

\begin{tabular}{l|ll}
\hline Variable & VIF & 1/VIF \\
\hline F1 & 1.00 & 1.000000 \\
F2 & 1.00 & 1.000000 \\
\hline Mean VIF & 1.00 & \\
\hline
\end{tabular}

According to the summary table above, $\mathrm{R}^{2}$ adjusted is 0.07 , that is, the prediction force of this model is $70 \%$, which indicates that the fitting degree is good, and the VIF value of the two 
factors in the analysis of the linear regression model is 1.00, indicating that there is no collinearity between the two factors entering the regression equation, and each factor is suitable for analysis at the same time (see Table 6 and 7). The multivariate linear equation is as follows:

$y=16.03+4.32$ F1-2.08 F2

(y : international tourism foreign exchange earning,

F1 : tourism environment factor, F2 : exchange rate factor)

\section{Results Analysis}

According to the regression results, the two factors are significant, which indicates that the two factors of tourism environment factor and exchange rate factor, have obvious effects on the dependent variable of international foreign exchange income. And as can be seen from the result table, the environment factor of the tourism industry is significant at the degree of 0.01 , which shows that this factor has a great impact on international foreign exchange earnings.

From the regression equation, the analysis results are as follows:

1. The environmental factor of the tourism industry has a positive effect on the tourism foreign exchange earnings of Zhejiang Province. The number of travel agencies, star hotels, A-level attractions, and international flights plays a decisive role in the development of tourism industry. The increase of travel agencies, A-level attractions and international flights is conducive to the development of the tourism industry in Zhejiang Province and the improvement of the international competitiveness of the tourism service trade. However, we can see from the results of the principal component analysis that the number of star hotels plays a negative role in the development of tourism. This may be because, with the development of the economy, some less developed hotels are gradually eliminated or merged into better hotels, resulting in the decrease of the number of hotels in the past decade (which is consistent with the trend of the original data collected).

2. The exchange rate factor has a negative effect on the tourism foreign exchange income of Zhejiang Province, indicating that the appreciation of RMB is not conducive to the export of tourism service trade. This is because the rise of the RMB exchange rate means the relative devaluation of US dollars and the decrease of people's disposable income, which will reduce people's willingness to travel abroad to a certain extent.

\section{Findings and Recommendations Research Conclusions}

Based on the relevant literature, this paper determines the research ideas, mainly from two perspectives to explore the international competitiveness of the tourism service trade in Zhejiang Province.

On the one hand, this paper makes descriptive statistics on the tourism service trade in Zhejiang Province. According to the collected data, this paper discusses the current situation of the development of the industry in Zhejiang Province and measures the competitiveness according to the relevant indicators. The main conclusions are as follows:

(1) The scale of the tourism service trade in Zhejiang Province has been expanding in recent ten years. In 2017, the foreign exchange income of international tourism in Zhejiang Province was more than twice that in 2010. The import and export volume of the tourism service trade accounted for nearly one-third of that of service trade, indicating that Zhejiang's Tourism has 
a strong comparative advantage over other service industries and plays an increasingly important role in Zhejiang's service trade.

(2) The development of the tourism service trade in different regions of Zhejiang Province is quite different. In 2018, the inbound tourists of Hangzhou accounted for half of the whole province, and the other eight cities accounted for the remaining half. The regional development of the tourism service trade is seriously unbalanced.

(3) According to the quantitative analysis of international competitiveness, the international market share of tourism service trade in Zhejiang Province is not low in the whole country and the trade competitiveness index shows that the competitiveness is also strong, but the revealed comparative advantage index and the competitive advantage index are not high, indicating that the tourism service trade in Zhejiang Province is large but not strong, and does not have a comprehensive international competitive advantage in the whole country International.

On the other hand, based on Porter's Diamond Model, this paper selects five main factors that affect the international competitiveness of the tourism service trade of Zhejiang Province and makes an empirical analysis using the data from 2007 to 2017. The main conclusions are as follows:

(1) The number of travel agencies, star hotels, A-level attractions, international flights, and the exchange rate has a significant impact on the competitiveness of the tourism service trade in Zhejiang Province. However, the number of star hotels and exchange rate have a negative effect on the tourism foreign exchange income of Zhejiang Province. That is because the number of hotels in Zhejiang Province has been reduced after the integration and adjustment, so that the service quality is better, which can give better service to inbound tourists.

(2) The appreciation of RMB is not conducive to the export of tourism service trade and will reduce people's willingness to travel abroad to a certain extent.

\section{Recommendations}

In order to achieve rapid development of tourism service trade in Zhejiang Province, we need to strengthen publicity, invest more capital, and strive to create a unique international tourism image of Zhejiang Province. Under the background of the belt and road, this will help Zhejiang's historical and cultural tourism positioning, upgrade the single tourism market to a comprehensive tour base with entertainment and learning, and create more opportunities for the sustainable development of the characteristic tourism. Zhejiang should take advantage of the concept of smart tourism, strengthen the development and construction of holiday circle, form a diversified tourism industry system of scenic spots, hot spring towns, and rural tourism, to meet the consumption needs of different international tourists, and improve the quality Zhejiang tourism.

Optimizing the tourism environment can create a good impression for the inbound tourists and make them get the best travel experience, which is very important to promote the development of tourism in Zhejiang Province. Tourists' feelings about scenic spots usually include space planning, hardware facilities, and supporting services, which form their experience. For Zhejiang Tourism, the optimization and integration of its many characteristic tourism resources will promote the increase of inbound tourists. Zhejiang Province has many natural and historical sites, which can bring people a different real feeling from the text. Therefore, modern science and technology can be used to exploit tourism resources creatively, providing tourists with experience travel of watching, reading, or perception, so that inbound tourists can learn and feel the history and culture of Zhejiang better. 
The development of the tourism service trade in a region is inseparable from the support of its related industries. According to the above analysis of influencing factors, the related supporting industries have a significant impact on the development of tourism in Zhejiang, so Zhejiang should improve the construction of transportation infrastructure and related industries. On the one hand, the construction of transportation facilities includes expanding the international flight routes, improving the traffic congestion near the scenic spots, and improving the traffic conditions between two scenic spots, to reduce the travel time of tourists and enhance the tour experience. On the other hand, it is necessary to strengthen the construction the development of tourism related supporting industries, such as the hotel service industry, travel agency industry, financial industry, etc., and establish a favorable industrial integration platform, which will not only promote the development of related industries in various regions but also effectively improve the efficiency and service quality, so as to improve their competitiveness.

\section{Research Significance}

Tourism service trade is an important industry for China, so the research on this is of great significance. In terms of theoretical value, as mentioned above, although there are many research results on the international competitiveness of service trade at home and abroad, the empirical research on it specifically is relatively less. The only relevant empirical researches are also based on the national level, and there are relatively few studies at the provincial level. This paper focuses on the empirical study of the international competitiveness of tourism service trade in Zhejiang Province, and based on Michael Porter's Diamond Model, constructs a multiple regression model to analyze the factors affecting of this competitiveness, which could enrich empirical research on the international competitiveness of tourism service trade from the provincial level.

In terms of practical value, Zhejiang Province is rich in tourism resources, where there are many natural and cultural landscapes with high ornamental value and rich cultural heritage. As a result, the tourism industry in Zhejiang has developed rapidly. In this paper, main factors affecting tourism competitiveness of Zhejiang are empirically analyzed, so as to learn the influencing factors of the improvement. Finally, based on the conclusions drawn from the analysis, corresponding countermeasures and suggestions are put forward, hoping that Zhejiang Province can make up for shortcomings and make further improvements to find a way to promote tourism service trade in regional coordinated development.

\section{References}

Chen, E., \& Cai, L. (2015). Empirical Analysis on the International Competitiveness and Influencing Factors of Macao's Tourism Service Trade. Journal of University of Finance and Economics, 28(01):56-62.

Crotts, J. C., Aziz, A., \& Raschid, A. (1998). Antecedents of Supplier's Commitment to Wholesale Buyers in the International Travel Trade. Tourism Management, 19(2), 127134.

Deasy, G. F., \& Griess, P. R. (1966). Impact of a Tourist Facility on its Hinterland. Annals of the Association of American Geographers, 56(2), 290-306.

Ge, L., \& Tian, J. (2011). Empirical Study on the International Competitiveness and Influencing Factors of Travel Services in Shanghai. Finance and Trade Research, 22(01):52-58.

Geng, X., \& Zhang, W. (2018). Analysis of the International Competitiveness of Tourism Service Trade of China and its Impacting Factors. Prices Monthly, (10):39-46. 
Guo, M. (2019). Comparison of the International Competitiveness of China's Tourism Service Trade-An Empirical Study Based on Extended Gravity Model. The World of Survey and Research, (09):61-65.

Hanna, J., Lévi, L., \& Petit, S. (2015). Intra-tourism Trade, Income Distribution and Tourism Endowment: An Econometric Investigation. Applied Economics, 47(21), 2184-2200.

Kesgin, M., Murthy, R. S., \& Pohland, L. W. (2019). Residents as Destination Advocates: The Role of Attraction Familiarity on Destination Image. Journal of Hospitality and Tourism Insights, 2(1), 55-74.

Li, Z., \& Zhao, Z. (2018). An Empirical Study on the Influencing Factors of the International Competitiveness of China's Tourism Service Trade-Based on the Grey Correlation Model. Journal of Commercial Economics, (16):139-141.

Liu, Q. (2019). A Research on Competitiveness Evaluation and Improvement Measures of China-ASEAN Tourism Service Trade. On Economic Problems, 483(11): 112-119.

Ohlin, B. (1967): Interregional and International Trade, revised edition (Harvard Economic Studies), Harvard University Press: Cambridge.

Porter, M. (1997). Trans. Chen, X., Competitiveness Advantage, Huaxia Press: Beijing.

Tadesse, B., \& White, R. (2012). Do Immigrants Enhance International Trade in Services? The Case of US Tourism Services Exports. International Journal of Tourism Research, 14(6):567-585.

Wang, D., \& Liu, X. (2014). An Empirical Analysis on the Influencing Factors of Tourism Industry Competitiveness-Taking Heilongjiang Province as an Example. Journal of Commercial Economics, (35):143-145.

Xiong, Z., Tang, J., \& Hong, X. (2019). Comparative Study on the International Competitiveness of Sino-US Tourism Service Trade. Asia-pacific Economic Review, 216(5):85-93,151.

Xuan, S. (2020). Research on the International Competitiveness of China's Service Trade from the Perspective of Global Value Chain. Statistics \& Decision, 36(17):101-105.

Zhang, J., \& Jensen, C. (2013). Trade in Tourism Services: Explaining Tourism Trade and the Impact of the General Agreement on Trade in Services on the Gains from Trade. Journal of International Trade \& Economic Development.

Zhang, J. (2017). Research on Competitiveness of Provincial Tourism Service Trade Based on Comprehensive Index System-Taking Zhejiang Province as an Example. Zhejiang Academic Journal, (01):214-221. 